\title{
Comparative Studies of the Biosorption of Heavy Metals (Zinc and Lead) using Tea Leaves (Cammelia Sinensis) and Tea Fibre as Adsorbents
}

\author{
Emmanuel E. Etim ${ }^{1 *}$, Etiowo George Ukpong ${ }^{2}$, Effiong O. Ekpenyong ${ }^{3}$, Godwin Oko E ${ }^{1}$ \\ ${ }^{l}$ Department of Chemical Sciences, Federal University Wukari, Taraba State, Nigeria \\ ${ }^{2}$ Department of Science Technology, Akwa Ibom State Polytechnic Ikot Osurua, Ikot Ekpene, \\ ${ }^{3,2}$ Department of Chemistry, College of Education, Afaha Nsit (Affiliated to University of Uyo), Akwa Ibom \\ State, Nigeria
}

*Corresponding Author: Emmanuel E. Etim, Department of Chemical Sciences, Federal University Wukari, Taraba State, Nigeria

\begin{abstract}
This research has helped us to ascend from the initial two exploratory studies to a more advanced general conclusion and theory that tea leaves (Camellia sinensis) has a great potential for $\mathrm{Pb}(\mathrm{ii})$ and $\mathrm{Zn}$ uptake, as such, a more suitable Low-cost adsorbent for the effective removal of $\mathrm{Pb}$ (II) and Zn from industrial effluents waste water than tea fibre. This is coined from the results of the different biosorption studies carried out as a function of contact time, initial metal ion concentration, biosorbent dosage and Pseudo first and second order models separately carried out on tea leaves and tea fibres
\end{abstract}

Keywords: biosorption; spectroscopy; physisorption; chemisorptions; adsorption; dosage; kinetics; Camellia sinensis.

\section{INTRODUCTION}

Heavy metals as described by Barrera et al., 2006 are elements whose density is equal to or greater than $6.0 \mathrm{~g} / \mathrm{cm}^{3}$ e.g Lead $(\mathrm{Pb})$, mercury $(\mathrm{Hg})$, cadmium $(\mathrm{Cd})$ and arsenic (As). They have for long been used by man in building materials, as medicine, as pigments or as additives for petrol (Hylander and Meili, 2003), (Järup, 2003). Researchers later proved that heavy metalsgenerally poses a great deal of problems to mankind due to its presence in the environment at concentrations above threshold(Seker et al., 2008).Anthropogenic activities such as industrial effluents, mining, smelting, manufacture of explosives, metal plating, domestic effluents, leaching and run-offs from garbage are responsible for the risen cases of these toxic elements in the environment(Trueby, 2003). and the danger associated to the presence of these heavy metals have been attributed to bioconcentration and bioaccumulation in the food web in different locations (Nussey, 1998) enhanced by their ability to be transported to a distance usually by water(Bradl, 2005). Heavy metal pollution of the environment is now one of the most serious environmental problems worldwide which calls for ways of remediation because they are acutely and exceedingly toxic, indestructible (non-biodegradable) and they bioaccumulates thereby causing different health complications e.g. lead poisoning damages the kidney, liver, brain, reproductive systems and even the nervous systems (Naiya et al., 2009). Also, excess ingestion of zinc can lead to microcytosis, impaired immune response, neutropenia and hypocupremia, (Appelo and Postma, 2007).

Thus, the removal of heavy metals including lead and zinc is therefore justified; this study evaluates the performance of Camellia sinensisbiomass as an adsorbent in the removal of lead and zinc from a contaminated aqueous phase or solution. The paper presents a momentous topic 'comparative studies of the biosorption of heavy metals (zinc and lead) using tea leaves (cammelia sinensis) and tea fibre as adsorbents'

The work is devised to enhance the use of natural available adsorbents such as Camellia sinensisbiomass instead of chemicals might give advantages such as lesser cost of production, source of income to the producer, source of revenue to the government as taxes from the sells, less sludge production and readily available materials and enhances sustainable development of agro-based waste. 


\section{MATERIALS AND MethodS}

\subsection{Materials}

Apparatus/reagents required are; volumetric flasks, Analytical balance, beakers, conical flasks, pipette, Mortar bland and pestle, centrifuge tubes, Filter papers, Centrifuge, $\mathrm{pH}$ meter, Atomic adsorption spectrometer. Lead (II) nitrate salt [Pb(NO3)2], Nitric acid (HNO3) or Hydrochloric acid $(\mathrm{HCl})$ sodium hydroxide salt $(\mathrm{NaOH})$, distilled water.

\subsection{Sample Collection}

Camellia sinensis (tea leaves and tea fiber), used for this analysis were obtained from Kakara High Land Tea, Sardauna L.G.A. Taraba state, Nigeria on JULY 2018.

\subsection{Methods}

\subsubsection{Prepaaration of Adsorbent}

The tea leaves (Camellia sinensis) obtained were sundried for one week (7 days) after which it was pulverized and sieved using a $150 \mathrm{~mm}$ sieve size. This sample was stored in an airtight polytene bag until analysis

\subsubsection{Preparation of Stock Solution}

$0.1 \mathrm{M}$ of lead (II) nitrate $\mathrm{Pb}(\mathrm{NO} 3) 2$ (R \& M marketing Essex U.K. with $\mathrm{MW}=331.20 \mathrm{~g} / \mathrm{mol}$ ). It was prepared for use throughout the experimental work. $33.12 \mathrm{~g}$ of lead (II) nitrate powder was dissolved in $500 \mathrm{~mL}$ of stock solution.

$0.1 \mathrm{M}$ of $\mathrm{Zn}(\mathrm{Mw}=287.38 \mathrm{~g} / \mathrm{mol})$. It was prepared for use throughout the experimental work. $28.738 \mathrm{~g}$ of zinc sulphide powder was dissolved in 500mL of stock solution. (Etim et al., 2019)

\subsubsection{Preparation of different Concentrations of Metal Solutions}

In this study, a total of 5 different concentrations of $\mathrm{Pb}^{2+}$ and $\mathrm{Zn}$ solutions were prepared: $0.02 \mathrm{M}$, $0.04 \mathrm{M}, 0.06 \mathrm{M}, 0.08 \mathrm{M}$ and $0.1 \mathrm{M}$. Subsequently, the lead and $\mathrm{Zn}$ solutions with different concentrations and biosorbent materials were required to be put into the orbital shaker (SSL1; Stuart ${ }^{\circledR}$ ) at different temperatures (between $30^{\circ} \mathrm{c}-60^{\circ} \mathrm{c}$ ). The rotational speed of shaker, in all the experiments, was kept constant at $220 \mathrm{rpm}$. This experiment was performed in duplicate and the best results were used. Lastly, the solution was filtered to prepare samples for the measurements of the metal ion concentration (Etim et al., 2019) and (Asuquo et al., 2019a,b,c)

\subsection{Effect of Initial Concentration}

$50 \mathrm{~mL}$ of each metal solution, containing different concentrations ;0.02 M, $0.04 \mathrm{M}, 0.06 \mathrm{M}$, and 0.08 $\mathrm{M}$ were measured into different conical flasks. $5 \mathrm{~g}$ of the biosorbent was dispersed in each of them, the flasks were corked and the mixture agitated with the aid of a shaker for 1 hour to attain equilibrium, the slurries were then filtered using Whatman filter paper and a plastic funnel, the filtrate was kept in well labelled containers and thereafter the concentrations of the resulting filtrate was determined using Atomic absorption spectrometer. (Reddad et al., 2002) and (Entezari et al., 2009).

\subsection{Effect of Biosorbent Dosage}

$2 \mathrm{~g}, 4 \mathrm{~g}, 6 \mathrm{~g}$, and $8 \mathrm{~g}$ of the adsorbent were weigh into different conical flasks. $50 \mathrm{ml}$ of each metal solution were measured into each of the conical flasks and labelled. The flasks were corked and the mixture agitated with the aid of a shaker for 1 hour to attain equilibrium, the slurries were then filtered using Whatman filter paper and a plastic funnel, the filtrate was kept in well labelled containers and thereafter the concentrations of the resulting filtrate was determined using Atomic absorption spectrometer. (Reddad et al., 2002) and (Entezari et al., 2009).

\subsection{Effect of Time (Time dependence)}

$5 \mathrm{~g}$ of biosorbent were suspended into different conical flasks containing $50 \mathrm{~mL}$ of metal solution. Each beaker was agitated on an electrical shaker/rotatory mixer at 30rpm with the time difference between each beaker were $10 \mathrm{~min}, 20 \mathrm{~min}, 30 \mathrm{~min}$ and $40 \mathrm{~min}$. Maintaining these parameters; temperature of $25 \mathrm{oc}, \mathrm{pH}$ of 6 , concentration of metal $0.1 \mathrm{M}$ Constant. Once the spinning is complete, the solute is extracted and placed into plastic centrifuge tubes after which it was centrifuged for $3 \mathrm{~min}$ at $6000 \mathrm{rpm}$. This enabled the separation of the biosorbent from the solution. 
Finally, the solution is extracted from the centrifuge tube using a dropper and it is placed in clean airtight bottles prior to analysis using atomic adsorption spectrometer (AAS) (Reddad et al., 2002),(Entezari et al., 2009) and (Etim et al., 2019).

\subsection{Estimation of Metal Uptake}

The metal uptake, qe, was determined using the following equation (Madhavi et al., 2011):

$q t=\frac{(\mathrm{Co}-\mathrm{Cf}) \mathrm{V}}{\mathrm{m}}$

Where

$\mathrm{q}_{\mathrm{e}}=$ metal ions per dry biosorbent $(\mathrm{mg} / \mathrm{g})$

$\mathrm{V}=$ volume of solution $(\mathrm{L})$

$\mathrm{C}_{\mathrm{o}}=$ initial concentration of metal in solution $(\mathrm{mg} / \mathrm{L})$

$\mathrm{C}_{\mathrm{f}}=$ final concentration of metal in solution $(\mathrm{mg} / \mathrm{L})$

$\mathrm{m}=$ the mass of biosorbent $(\mathrm{g})$

\section{RESULTS AND DisCUSSION}

\subsection{Comparing the Effect of Adsorbent Dosage (Between Tea Leaves and Tea Fiber) for the Removal of $\mathrm{Pb}$ and $\mathrm{Zn}$ from Aqueous Phase}

As shown in table 1 and 2, similar dosage measurement was applied in both the assessment, the percentage biosorption was high ranging from $98.81 \%-99.95 \%$ sorption, with a constant increase in the dosages. There was a slight decrease in \% biosorption of $\mathrm{Pb}$ in tea fibre, this confirms (Beatti et al., 2007) statement in their work on heavy metals that it might be as a result of the aggregation of much adsorbents and adsorbates ions. These findings from the two research narrows our understanding to an assumption that an increase in the amount of adsorbent dosage leads to a gradual increase in the amount or percentage biosorption both in tea leaves and tea fibers.

Table1. Adsorbent dose data for removal of Lead and Zinc from aqueous phase using Camellia Sinensis (tea leaves)

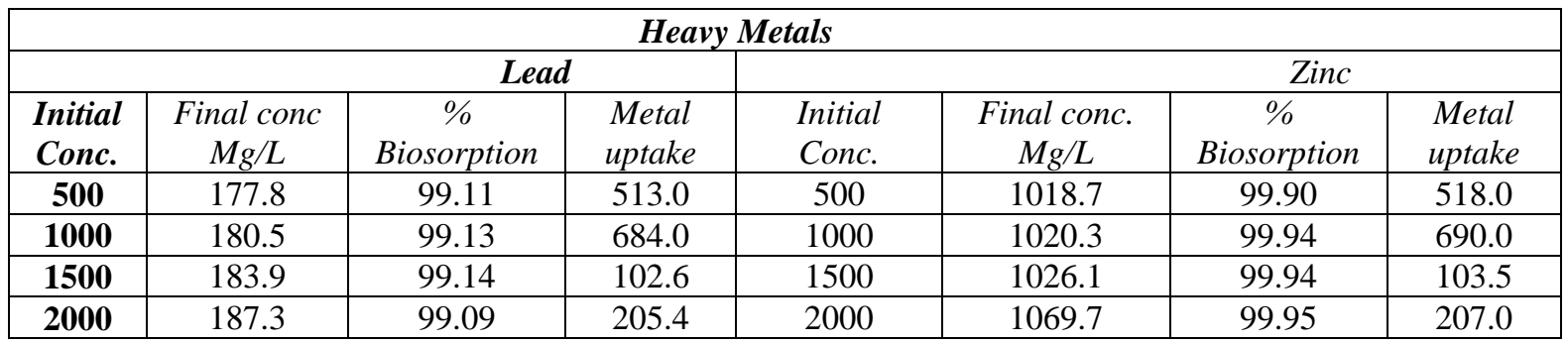

Table2. Adsorbent dose data for removal of Lead and Zinc from aqueous phase using Camellia Sinensis (Tea fibre)

\begin{tabular}{|c|c|c|c|c|c|c|c|}
\hline \multicolumn{8}{|c|}{ Heavy Metals } \\
\hline \multicolumn{4}{|c|}{ Lead } & \multicolumn{4}{|c|}{ Zinc } \\
\hline $\begin{array}{c}\text { Adsorbent } \\
\text { dosage(g) }\end{array}$ & $\begin{array}{c}\text { Final conc } \\
\qquad \mathrm{Mg} / \mathrm{L}\end{array}$ & $\begin{array}{c}\% \\
\text { Biosorption }\end{array}$ & $\begin{array}{l}\text { Metal } \\
\text { uptake }\end{array}$ & $\begin{array}{l}\text { Adsorbent } \\
\text { dosage }(g)\end{array}$ & $\begin{array}{c}\text { Final conc. } \\
\qquad \mathrm{Mg} / \mathrm{L}\end{array}$ & $\begin{array}{c}\% \\
\text { Biosorption }\end{array}$ & $\begin{array}{l}\text { Metal } \\
\text { uptake }\end{array}$ \\
\hline 500 & 240.392 & $\begin{array}{lllll}9 & 8 & . & 8 & 4 \\
\end{array}$ & 2047.9608 & 500 & 10.456 & 99.84 & 326.3772 \\
\hline 1000 & 238.020 & 98.85 & 1024.0090 & 1000 & 7.802 & 99.88 & 326.5099 \\
\hline 1500 & 247.442 & $\begin{array}{lllll}9 & 8 & . & 8 & 1 \\
\end{array}$ & 682.4186 & 1500 & 7.545 & 99.89 & 326.5228 \\
\hline 2000 & 242.151 & $\begin{array}{lllll}9 & 8 & . & 8 & 3 \\
\end{array}$ & 511.9462 & 2000 & 7.602 & 99.88 & 326.5199 \\
\hline
\end{tabular}

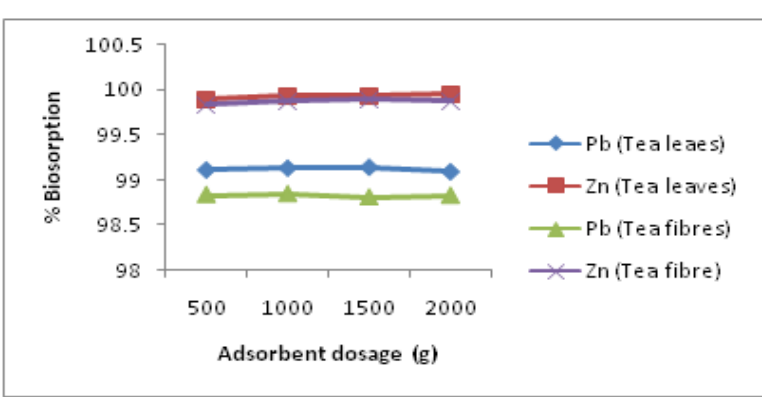

Figure1. Adsorbent dose chart comparing the removal of Lead and Zinc from aqueous phase using Camellia Sinensis Tea leaves and Tea fibre 
Comparative Studies of the Biosorption of Heavy Metals (Zinc and Lead) using Tea Leaves (Cammelia Sinensis) and Tea Fibre as Adsorbents

Also, more elucidation carried out as shown in figure 1 below revealed that tea leaves are better adsorbents than tea fibre with an increasing dosage especially in the removal of Zinc, when all other factors are kept constant. This finding supports (Etim et al., 2019) work on tea leaves

\subsection{Comparing the Effect of Initial Ion Concentration on Tea Leaves and Tea Fibre}

Table3. Effect of Initial concentration data for the removal of lead and zinc from aqueous phase using Camellia Sinensis.(tea leaves)

\begin{tabular}{|c|c|c|c|c|c|c|c|}
\hline \multicolumn{8}{|c|}{ Heavy Metals } \\
\hline \multicolumn{4}{|c|}{ Lead } & \multicolumn{4}{|c|}{ Zinc } \\
\hline $\begin{array}{l}\text { Initial } \\
\text { Conc. }\end{array}$ & $\begin{array}{c}\text { Final conc } \\
\mathrm{Mg} / \mathrm{L}\end{array}$ & $\begin{array}{c}\% \\
\text { Biosorption }\end{array}$ & $\begin{array}{l}\text { Metal } \\
\text { uptake }\end{array}$ & $\begin{array}{l}\text { Initial } \\
\text { Conc. }\end{array}$ & $\begin{array}{c}\text { Final conc. } \\
\qquad \mathrm{Mg} / \mathrm{L}\end{array}$ & $\begin{array}{c}\% \\
\text { Biosorption }\end{array}$ & $\begin{array}{l}\text { Metal } \\
\text { uptake }\end{array}$ \\
\hline 13076 & 144.8 & 98.89 & 646 & 13076 & 958.1 & 99.93 & 653.0 \\
\hline 26152 & 169.5 & 99.35 & 1299 & 26152 & 996.2 & 99.94 & 130.7 \\
\hline 39228 & 179.1 & 99.54 & 1952 & 39228 & 1026.4 & 99.95 & 196.0 \\
\hline 52304 & 183.9 & 99.64 & 2606 & 52304 & 1069.7 & 99.95 & 261.5 \\
\hline
\end{tabular}

Table4. Effect of Initial concentration data for the removal of lead and zinc from aqueous phase using

Camellia Sinensis (tea fibre)

\begin{tabular}{|c|c|c|c|c|c|c|c|}
\hline \multicolumn{8}{|c|}{ Heavy Metals } \\
\hline \multicolumn{4}{|c|}{ Lead } & \multicolumn{4}{|c|}{ Zinc } \\
\hline $\begin{array}{l}\text { Initial } \\
\text { Conc. }\end{array}$ & $\begin{array}{l}\text { Final conc } \\
\mathrm{Mg} / \mathrm{L}\end{array}$ & $\begin{array}{c}\% \\
\text { Biosorption }\end{array}$ & $\begin{array}{l}\text { Metal } \\
\text { uptake }\end{array}$ & $\begin{array}{l}\text { Initial } \\
\text { Conc. }\end{array}$ & $\begin{array}{c}\text { Final conc. } \\
\mathrm{Mg} / \mathrm{L}\end{array}$ & $\begin{array}{c}\% \\
\text { Biosorption }\end{array}$ & $\begin{array}{l}\text { Metal } \\
\text { uptake }\end{array}$ \\
\hline 4144 & 2000.612 & $95 \quad 5 \quad 6 \quad 0$ & 197.1694 & 1307.6 & 6.887 & 99.47 & 65.0357 \\
\hline 8288 & $2 \begin{array}{llllll}2 & 3 & 7 & 0 & 2 & 3\end{array}$ & $\begin{array}{lllll}9 & 7 & . & 1 & 4\end{array}$ & 402.5488 & 2615.2 & 7.224 & 99.72 & 130.3988 \\
\hline 12432 & 163 & $\begin{array}{lllll}9 & 8 & . & 1 & 4\end{array}$ & 610.0418 & 3922.8 & 7.487 & 99.80 & 195.748 \\
\hline 16576 & $\begin{array}{lll}6 & 8 & 1\end{array}$ & .52 & 816.5159 & 5230.4 & 7.754 & 99.85 & 261.323 \\
\hline
\end{tabular}

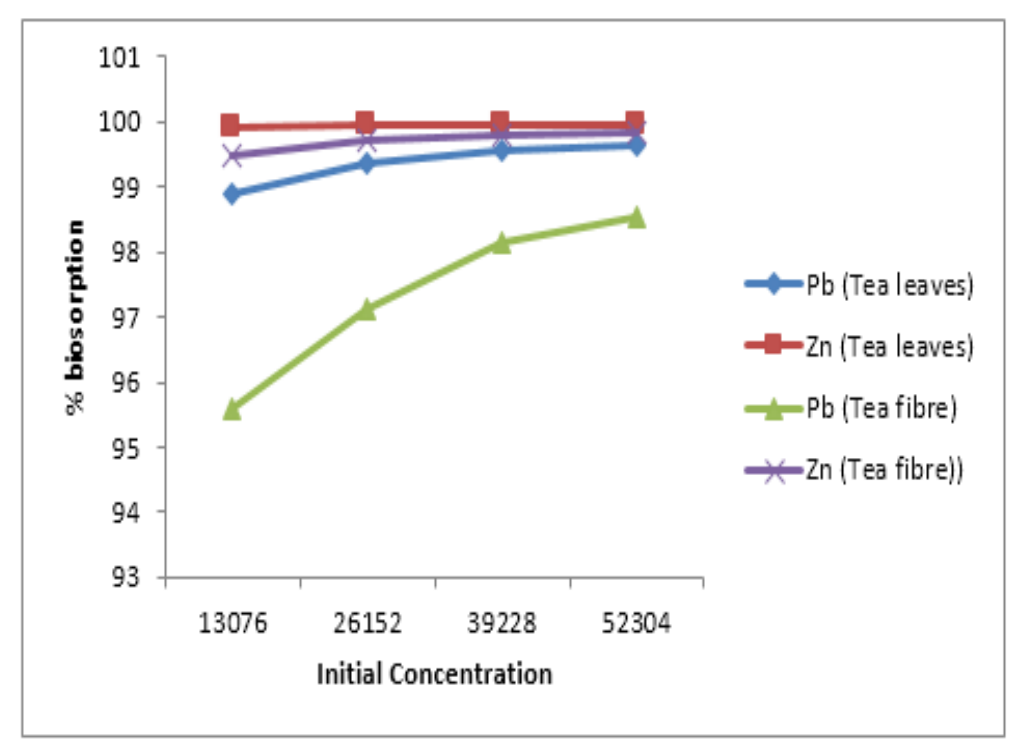

Figure2. Comparing the effect of Initial ion concentration on tea leaves and tea fibre.

Considering the initial ion concentration of adsorbent data obtained from the analysis of the ability of tea leaves and tea fibers to remove $\mathrm{Pb}$ and $\mathrm{Zn}$ from an aqueous media with initial concentration of the ions known are presented in table 3 and table 4 respectively, as incorporated in figure 2 for a better understanding, the role of tea leaves in the removal of $\mathrm{Zn}$ was highest with a high \% biosorption ( up to $99.95 \%$ ) followed bytea fibre.

More so, tea leavesr functioned more in the removal or $\%$ biosorption of $\mathrm{Pb}$ than tea fibres at the same initial concentrations of the metal ion, but it can be seen that presence of more $\mathrm{Pb}$ ions or increase in the initial concentration does not affect the uptake of $\mathrm{Zn}$ ions, rather more $\mathrm{Pb}$ ions were left in the solution with tea leaves adsorbent. Therefore, the effect of initial ion concentration $\mathrm{Pb}$ and $\mathrm{Zn}$ places preference on tea fiber over tea leaves since it showed a higher \% biosorption for the heavy metals under study. 
Comparative Studies of the Biosorption of Heavy Metals (Zinc and Lead) using Tea Leaves (Cammelia Sinensis) and Tea Fibre as Adsorbents

\subsection{Comparing the Effect of Contact Time (With Tea Leaves and Tea Fiber) for The Removal o of $\mathrm{Pb}$ and $\mathrm{Zn}$ from Aqueous Phase}

Table5.Contact time for removal of Lead and Zinc from aqueous phase using Camellia Sinensis (tea leaves)

\begin{tabular}{|c|c|c|c|c|c|c|c|}
\hline \multicolumn{9}{|c|}{ Heavy Metals } \\
\hline \multicolumn{7}{|c|}{ Lead } \\
\hline Time(min) & $\begin{array}{c}\text { Final conc } \\
\text { Mg/L }\end{array}$ & $\begin{array}{c}\% \\
\text { Biosorption }\end{array}$ & $\begin{array}{c}\text { Metal } \\
\text { uptake }\end{array}$ & Time(min) & $\begin{array}{c}\text { Final conc. } \\
\text { Mg/L }\end{array}$ & $\begin{array}{c}\% \\
\text { Biosorption }\end{array}$ & $\begin{array}{c}\text { Metal } \\
\text { uptake }\end{array}$ \\
\hline $\mathbf{1 0}$ & 175.8 & 99.15 & 102.7 & 10 & 716.1 & 99.96 & 103.6 \\
\hline $\mathbf{2 0}$ & 164.9 & 99.11 & 262.6 & 20 & 618.3 & 99.97 & 202.0 \\
\hline $\mathbf{3 0}$ & 159.4 & 99.18 & 302.8 & 30 & 318.3 & 99.98 & 249.2 \\
\hline $\mathbf{4 0}$ & 140.3 & 99.20 & 502.7 & 40 & 119.6 & 99.99 & 480.9 \\
\hline
\end{tabular}

Table6. Contact time for removal of Lead and Zinc from aqueous phase using Camellia Sinensis (tea fibre)

\begin{tabular}{|c|c|c|c|c|c|c|c|}
\hline \multicolumn{9}{|c|}{ Heavy Metals } \\
\hline \multicolumn{2}{|c|}{ Lead } & \multicolumn{2}{c|}{ Zinc } \\
\hline Time(min) & $\begin{array}{c}\text { Final conc } \\
\text { Mg/L }\end{array}$ & $\begin{array}{c}\% \\
\text { Biosorption }\end{array}$ & $\begin{array}{c}\text { Metal } \\
\text { uptake }\end{array}$ & Time(min) & $\begin{array}{c}\text { Final conc. } \\
\text { Mg/L }\end{array}$ & $\begin{array}{c}\% \\
\text { Biosorption }\end{array}$ & $\begin{array}{c}\text { Metal } \\
\text { uptake }\end{array}$ \\
\hline $\mathbf{1 0}$ & 35.347 & 99.83 & 1634.2326 & 10 & 6.2480 & 99.90 & 326.5876 \\
\hline $\mathbf{2 0}$ & 10.637 & 99.95 & 1634.2326 & 20 & 10.247 & 99.84 & 326.3877 \\
\hline $\mathbf{3 0}$ & 3.012 & 99.98 & 1035.8494 & 30 & 10.464 & 99.84 & 326.3768 \\
\hline $\mathbf{4 0}$ & 2.738 & 99.99 & 1035.8631 & 40 & 10.772 & 99.84 & 326.3614 \\
\hline
\end{tabular}

From the observation and then in general, we can resolve that, For a prolonged exposure, the $\%$ biosorption of $\mathrm{Pb}$ and $\mathrm{Zn}$ increases using both tea leaves and tea fibre. In a prolonged exposure, tea leaf is more efficient in the removal of $\mathrm{Zn}$ than $\mathrm{Pb}$, as shown from the data obtained during the analysis and presented in table 5, while table 6 shows that at a longer time, the $\%$ biosorption of $\mathrm{Pb}$ increases gradually. This finding is also in line with (Hanif and Akhtar, 2007) who stated that adsorption increases initially at increase in contact time because initially, all the binding sites are available and so the adsorb ate ion easily becomes bonded to the sites. It's shown in figure 3 below. Comparatively, the performance of tea leaves in the biosorption is higher than that of tea fibre over time

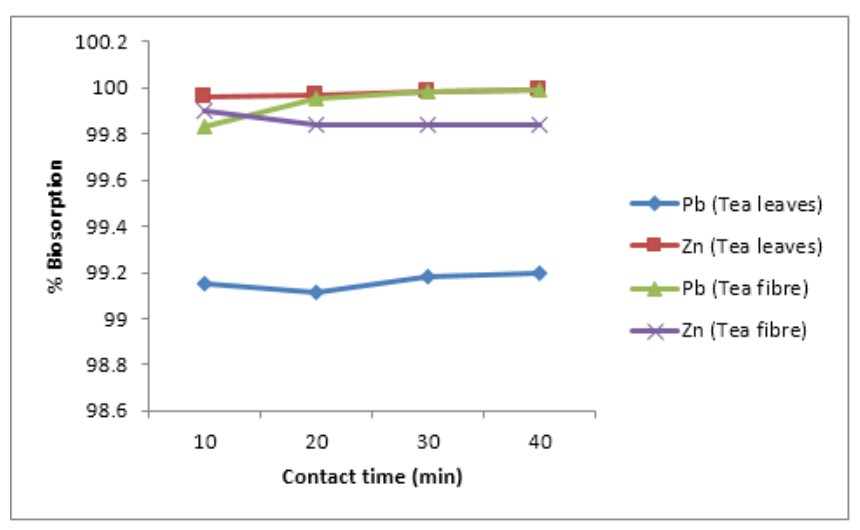

Figure3. Comparing the effect of contact time (with tea leaves and tea fiber) for the removal of $\mathrm{Pb}$ and $z \mathrm{n}$ from aqueous phase

\subsection{Comparing the Kinetics of Biosorption of Lead and Zinc Using Tea Leaves and Tea Fiber}

\subsubsection{Lagergren Pseudo First-Order}

The lagergren Pseudo first-order reaction was used to describe the kinetics with the linear equation form shown below

$\log (q e-q t)=\log q e-\frac{K 1 t}{2.303}(2)$

Where qe $(\mathrm{mg} / \mathrm{g})$, qt $(\mathrm{mg} / \mathrm{g})$ are adsorption capacity at equilibrium and at time $\mathrm{t}$, respectively. $\mathrm{K} 1$ is the rate constant of pseudo first-order adsorption $(\mathrm{L} / \mathrm{min})$. The value of the constants qe, $\mathrm{k} 1$ and $\mathrm{R} 2$ obtained from the linear plot of $\log (\mathrm{qe}-\mathrm{qt})$ vs $\mathrm{t}$ 
Comparative Studies of the Biosorption of Heavy Metals (Zinc and Lead) using Tea Leaves (Cammelia Sinensis) and Tea Fibre as Adsorbents

Table7. First order kinetic of biosorption of Lead and Zinc using tea leaves

\begin{tabular}{|c|c|c|c|c|c|c|c|c|c|}
\hline \multicolumn{10}{|c|}{ Heavy Metals } \\
\hline \multicolumn{5}{|c|}{ Lead } & \multicolumn{5}{|c|}{ Zinc } \\
\hline Time(min) & $\begin{array}{l}\text { Final } \\
\text { conc } \\
M g / L\end{array}$ & $\begin{array}{c}\% \\
\text { Biosorption } \\
q e \\
\end{array}$ & $\begin{array}{c}\text { Metal } \\
\text { uptake } \\
\text { qt }\end{array}$ & $\begin{array}{c}\log \\
(\mathrm{qt}-\mathrm{qe})\end{array}$ & Time(min) & $\begin{array}{l}\text { Final } \\
\text { conc } \\
M g / L\end{array}$ & $\begin{array}{c}\% \\
\text { Biosorption } \\
q e\end{array}$ & $\begin{array}{c}\text { Metal } \\
\text { uptake } \\
\text { qt }\end{array}$ & $\begin{array}{c}\log \\
(\mathrm{qt}-\mathrm{qe})\end{array}$ \\
\hline 10 & 175.8 & 99.15 & 102.7 & 0.55022 & 10 & 716.1 & 99.96 & 103.6 & 0.5599 \\
\hline 20 & 164.9 & 99.11 & 262.6 & 2.2134 & 20 & 618.3 & 99.97 & 202.0 & 2.0087 \\
\hline 30 & 159.4 & 99.18 & 302.8 & 2.3088 & 30 & 318.3 & 99.98 & 249.2 & 2.1738 \\
\hline 40 & 140.3 & 99.20 & 502.7 & 2.6058 & 40 & 119.6 & 99.99 & 480.9 & 2.5808 \\
\hline
\end{tabular}

Table8. First order kinetic of biosorption of Lead and Zinc using tea fibre

\begin{tabular}{|c|c|c|c|c|c|c|c|c|c|}
\hline \multicolumn{10}{|c|}{ Heavy Metals } \\
\hline \multicolumn{5}{|c|}{ Lead } & \multicolumn{5}{|c|}{ Zinc } \\
\hline Time(min) & $\begin{array}{l}\text { Final } \\
\text { conc } \\
\mathrm{Mg} / \mathrm{L}\end{array}$ & $\begin{array}{c}\% \\
\text { Biosorption } \\
q e\end{array}$ & $\begin{array}{c}\text { Metal } \\
\text { uptake qt }\end{array}$ & $\begin{array}{c}\log (q t- \\
q e)\end{array}$ & Time(min) & $\begin{array}{l}\text { Final } \\
\text { conc } \\
\mathrm{Mg} / \mathrm{L}\end{array}$ & $\begin{array}{c}\% \\
\text { Biosorption } \\
q e\end{array}$ & $\begin{array}{l}\text { Metal } \\
\text { uptake }\end{array}$ & $\begin{array}{c}\log (q t- \\
q e)\end{array}$ \\
\hline 10 & 35.347 & 99.83 & 1634.2326 & 3.1859 & 10 & 6.2480 & 99.90 & 326.5876 & 2.3554 \\
\hline 20 & 10.637 & 99.95 & 1634.2326 & 3.1859 & 20 & 10.247 & 99.84 & 326.3877 & 2.3551 \\
\hline 30 & 3.012 & 99.98 & 1035.8494 & 2.9712 & 30 & 10.464 & 99.84 & 326.3768 & 2.3551 \\
\hline 40 & 2.738 & 99.99 & 1035.8631 & 2.9712 & 40 & 10.772 & 99.84 & 326.3614 & 2.3551 \\
\hline
\end{tabular}

The data used for the Pseudo first-oder kinetics are contained in table 7 and 8 above, and the linear plot is shown in figure 4 below comparing tea leaves and tea fibers on the adsorption of $\mathrm{Pb}$ and $\mathrm{Zn}$. The result of the Pseudo first-oder kinetics best fitted adsorption of $\mathrm{Zn}$ on tea leaves with regression coefficient $\mathrm{R}^{2}=0.833$, followed by the adsorption of $\mathrm{Pb}$ in tea fibre with a regression coefficient of $\mathrm{R} 2=0.8$ and moderately fitted the adsorption of $\mathrm{Pb}$ in tea leaves with a regression coefficient of $\mathrm{R} 2=$ $0.758 \mathrm{nd} \mathrm{Zn}$ in tea leaves with $\mathrm{R} 2=0.6$. This implies that the reaction involving tea fiber favors (more inclined) towards physisorption than tea leaves since it values are close to 1 .

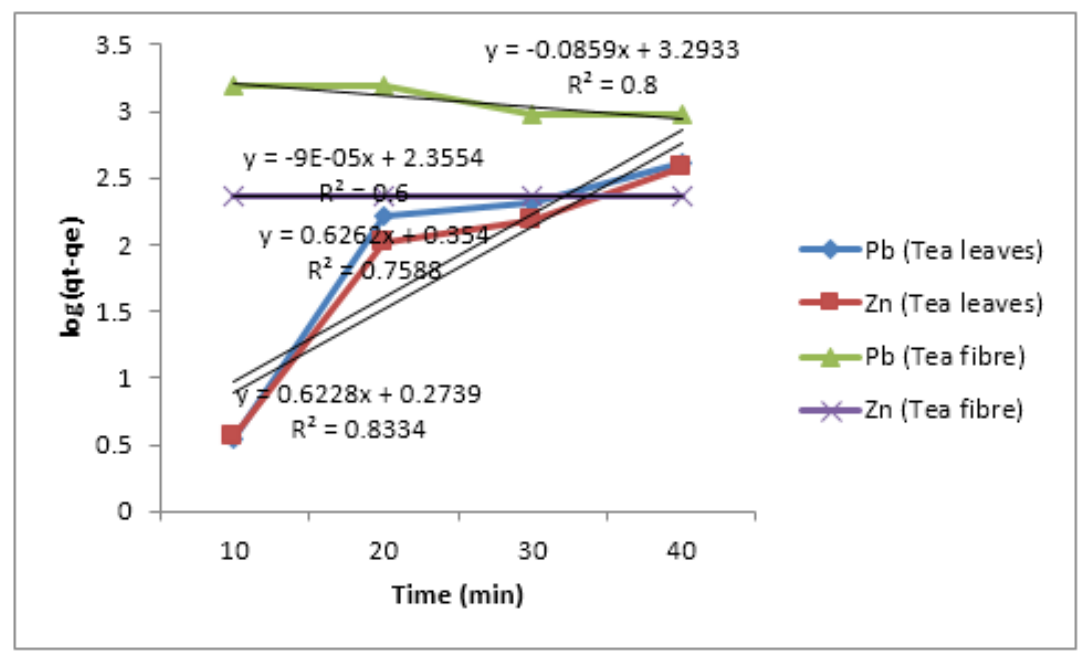

Figure4. First order kinetic comparing the biosorption of $\mathrm{Pb}$ and $\mathrm{Zn}$ using tea leaves and tea fibre.

\subsubsection{Pseudo Second-Order Model}

Table9. second order kinetic of biosorption of Lead and Zinc using tea leavs

\begin{tabular}{|c|c|c|c|c|c|c|c|c|c|}
\hline \multicolumn{10}{|c|}{ Heavy Metals } \\
\hline \multicolumn{5}{|c|}{ Lead } & \multicolumn{5}{|c|}{ Zinc } \\
\hline Time(min) & $\begin{array}{c}\text { Final } \\
\text { conc } \\
M g / L\end{array}$ & $\begin{array}{c}\% \text { Biosorption } \\
q e\end{array}$ & $\begin{array}{c}\text { Metal } \\
\text { uptake qt }\end{array}$ & $\mathrm{t} / \mathrm{qt}$ & Time(min) & $\begin{array}{c}\text { Final } \\
\text { conc } \\
M g / L\end{array}$ & $\begin{array}{c}\% \text { Biosorption } \\
q e\end{array}$ & $\mid \begin{array}{c}\text { Metal } \\
\text { uptake qt }\end{array}$ & $\mathrm{t} / \mathrm{qt}$ \\
\hline 10 & 175.8 & 99.15 & 102.7 & 0.0973 & 10 & 716.1 & 99.96 & 103.6 & 0.0965 \\
\hline 20 & 164.9 & 99.11 & 262.6 & 0.0761 & 20 & 618.3 & 99.97 & 202.0 & 0.0990 \\
\hline 30 & 159.4 & 99.18 & 302.8 & 0.0990 & 30 & 318.3 & 99.98 & 249.2 & 0.1203 \\
\hline 40 & 140.3 & 99.20 & 502.7 & 0.0795 & 40 & 119.6 & 99.99 & 480.9 & 0.0831 \\
\hline
\end{tabular}


Comparative Studies of the Biosorption of Heavy Metals (Zinc and Lead) using Tea Leaves (Cammelia Sinensis) and Tea Fibre as Adsorbents

Table10. second order kinetic of biosorption of Lead and Zinc using tea fibre

\begin{tabular}{|c|c|c|c|c|c|c|c|c|c|}
\hline & & & & \multicolumn{6}{|c|}{ Heavy Metals } \\
\hline \multicolumn{5}{|c|}{ Lead } & \multicolumn{5}{|c|}{ Zinc } \\
\hline Time(min) & $\begin{array}{l}\text { Final } \\
\text { conc } \\
M g / L\end{array}$ & $\begin{array}{c}\% \\
\text { Biosorption } \\
q e \\
\end{array}$ & $\begin{array}{c}\text { Metal } \\
\text { uptake qt }\end{array}$ & $\mathrm{t} / \mathrm{qt}$ & Time(min) & $\begin{array}{l}\text { Final } \\
\text { conc } \\
M g / L\end{array}$ & $\begin{array}{c}\% \\
\text { Biosorption } \\
q e \\
\end{array}$ & $\begin{array}{l}\text { Metal } \\
\text { uptake }\end{array}$ & $\mathrm{t} / \mathrm{qt}$ \\
\hline 10 & 35.347 & 99.83 & 1634.2326 & 0.0061 & 10 & 6.248 & 99.90 & 326.5876 & 0.0306 \\
\hline 20 & 10.637 & 99.95 & 1634.2326 & 0.0122 & 20 & 10.247 & 99.84 & 326.3877 & 0.0612 \\
\hline 30 & 3.012 & 99.98 & 1035.8494 & 0.0289 & 30 & 10.464 & 99.84 & 326.3768 & 0.0919 \\
\hline 40 & 2.738 & 99.99 & 1035.8631 & 0.0386 & 40 & 10.772 & 99.84 & 326.3614 & 0.1225 \\
\hline
\end{tabular}

The Pseudo second order equation is shown below and the model is based on the assumption that the rate determining step is chemisorptions (Das and mondal, 2011).

$\frac{t}{q t}=\frac{1}{K 2 q e 2}+\frac{t}{q e}(3)$

Where $\mathrm{K} 2$ = Rate constant $(\mathrm{g} / \mathrm{mg} / \mathrm{min})$ of pseudo second- order adsorption rate constant. The values of $\mathrm{k} 2$, R2 and qe were obtained from the plots of t/qt versus t of lead and zinc (Table 9 and 10) as shown in figure 5 below. The correlation coefficient of R2 = 1 and R2 = 0.964 for the adsorption of $\mathrm{Zn}$ and $\mathrm{Pb}$ respectively from tea fibre indicates that the reaction is more inclined towards chemisorptions and Pseudo second order kinetics provides the best fit for the adsorption of $\mathrm{Pb}$ and $\mathrm{Zn}$ in tea fibre than $\mathrm{Pb}$ and $\mathrm{Zn}$ in tea leaves whose correlation coefficients $\mathrm{R} 2=0.025$ and 0.110 respectively

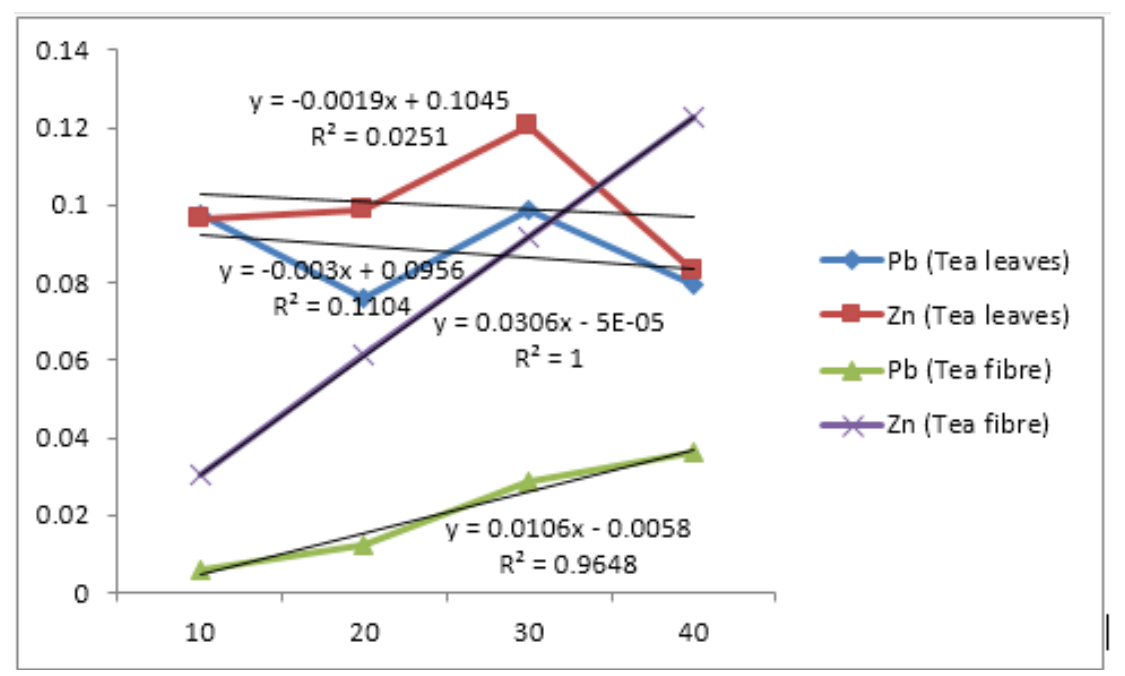

Figure5. Second order kinetics

\section{CONClusion}

Comparatively, The finding showed that Tea leavesare very effective and better biosorbent for the clearing and removal of $\mathrm{Pb}$ and $\mathrm{Zn}$ ions froman aqueous phase compared to tea leaves all of Camellia sinensis. This conclusion was derived from the comparative analysis of the percentage biosorption of the two Camellia sinensis in the form of tea leaves and tea fibers that were examined, as a function of adsorbents dosage, initial metal ion concentration and contact time. kinetics of the biosorption showed that the processes of the adsorption was feasible as the adsorption data fits more into Langergren Pseudo first-order kinetics for $\mathrm{Zn}$ and $\mathrm{Pb}$ in tea leaves and tea fibres respectively while a good fit of the adsorption data of tea fibre was found only to fit more into Pseudo second-order kinetics for both $\mathrm{Pb}$ and $\mathrm{Zn}$. The research therefore presents tea leaves which is a a very cheap and low cost by-product of tea processing as an effective biosorbent.

\section{REFERENCES}

[1] Appelo, C. A. J. and Postma, D. (2007).Geochemistry, groundwater and pollution. aqueous solutions by green algae Spirogyra species. Water Res, 25, 4079-4085.

[2] Asuquo, J. E., Ugwuja, D. I., Etim, E. E (2017). Effect of Time on the Adsorption of Metallic Soaps

[3] onto Hematite in Aqueous Media. International Journal of Modern Chemistry, 9(1): 69-77.

[4] Asuquo, J. E., Anusiem, A. C. I., and Etim, E. E (2012a). Comparative study of the effect of 
[5] Temperature on the adsorption of metallic soaps of shea butter, castor and rubber seed oils onto

[6] Hematite. International Journal of Modern Chemistry, 3(1): 39-50.

[7] Asuquo, J. E., Anusiem, A. C. I., and Etim, E. E (2012b). Studies on the Effect of pH on the

[8] Adsorption of the Metallic Soaps of Shear Butter, Castor and Rubber Seed Oils. International

[9] Journal of Modern Engineering Sciences, 1(3): 105-117.

[10] Asuquo, J. E., Anusiem, A. C. I and Etim, E. E (2012c). Studies on the Effects of PH and

[11] Temperature on the Adsorption of Metallic Soaps of Castor Seed Oil. International

[12] Journal of Chemical Sciences, 5(2): 248-252.

[13] Barrera, H., F. Urena-Nunez, B. Bilyeu and C.B. Diaz, Removal of chromium and toxic ions present in mine drainage by Ectodermis of opuntia. J. Hazarrd. Matter., 2006, 146: 270-277.

[14] Bradl, H. B. (2005). Sources and Origins of Heavy Metals. In Heavy Metals in the Environment; origin, interaction and remediation, (ed. H. B. Bradl)

[15] Beattie, A. D., Moore, M. R. \& Goldberg, A., et al., (2007).Role of chronic low-lead

[16] Das, B., \&Mondal, N. K. (2011).Calcerous soils as a new adsorbent to remove lead from aqueous solution: equilibrium, kinetics and thermodynamic studies. Univ.j.Env.Res.Tech., vol 1, 4;515- 530

[17] Enteyari (2009). Biosorption of reactive dye from textile wastewater by non-viable biomass of Aspergillus niger and Spirogyra sp., Science Direct. Bioresource Technology 99, 6631-6634.

[18] Etim, E. E.; David, D.' Godwin, O. E (2019). Kinetic Studies of the Biosorption of Zn and Pb (ii)

[19] from Solution Using Tea Fibre. International Journal of Modern Chemistry, 11(1): 57-72

[20] Etim, E. E.; Japhet, J.' Godwin, O. E, Effiong O. Ekpenyong (2019). Kinetic Studies of the Biosorption of $\mathrm{Zn}$ and $\mathrm{Pb}$ (ii) from Solution Using Tea leaves. International Journal of Environment and Bioenergy, 14(1): 83-93

[21] Hanif, M.A., \& Akhtar, K. (2007).Nickel (II) biosorption by Casia fistula biomass.J. Hazard mater, 139(2), 345-355.

[22] Hylander, L. D. and Meili, M. (2003).500 years of mercury production: global annual inventory International Conference On Mining And The Environment III, Sudbury, Ontario,

[23] Järup, L. (2003). Hazards of heavy metal contamination. Brit. Med. Bull. 68, 167-182.

[24] Madhavi (2011). Studies on the accumulation of heavy metal elements in biological systems: Accumulation of uranium by microorganisms. Eur J Appl microbial Biotechnol, 12, 90-96.

[25] Naiya, T.K., Bhattacharya, A.K., and Das, S.K. 2009. “Clarified Sludge (Basic Oxygen Furnace Sludge) An Adsorbent for Removal of Pb(II) from Aqueous Solutions: Kinetics, Thermodynamics and Desorption Studies". Journal of Hazardous Materials.170:252-262.

[26] Nussey, G. (1998). Metal ecotoxicology of the upper Olifants River at selected localities and the effect of copper and zinc on fish blood physiology. Ph.D-thesis, Rand Afrikaans University, South Africa

[27] Reddad (2002). "Biosorbents for recovery of metals from industrial solutions". Biotechnology Left, 10, 137-142.

[28] Şeker, A., Shahwan, T., Eroğlu, A.E., Yilmaz, S., Demirel, Z., and Dalay, M.C. 2008. "Equilibrium, Thermodynamic and Kinetic Studies for the Biosorption of Aqueous Lead (II), Cadmium (II), and Nickel (II) Ions on Spiuilina platensis ".Journal Hazardous Materials. 154:973-980.

[29] Trueby, P. (2003). Impact of Heavy Metals on Forest Trees from Mining Areas.

Citation: Emmanuel E. Etim, et.al, "Comparative Studies of the Biosorption of Heavy Metals (Zinc and Lead) using Tea Leaves (Cammelia Sinensis) and Tea Fibre as Adsorbents”, International Journal of Advanced Research in Chemical Science, vol. 6, no. 9, p. 20-27, 2019. DOI: http://dx.doi.org/10.20431/23490403.0609003

Copyright: (C) 2019 Authors. This is an open-access article distributed under the terms of the Creative Commons Attribution License, which permits unrestricted use, distribution, and reproduction in any medium, provided the original author and source are credited. 